\title{
HACIA UNA LECTURA DE BARROCO, DE SEVERO SARDUY
}

\author{
POR \\ ARMANDO ROMERO \\ University of Pittsburgh
}

\section{EMPLAZAMIENTOS}

La sensación de vértigo probablemente se origina en ese «nada puede situarnos», tan propio del barroco, tan caro a la teoría de la relatividad. Así, emprender el camino de aprehender lo barroco, aunque sea de la mano lúcida de Severo Sarduy ${ }^{1}$, no deja de conducirnos a ese lugar donde el orden origina un desorden, y viceversa, a ese no existente punto donde la retórica desaparece envuelta en sí misma para surgir como libertad, donde más bien hablar es crear volúmenes, superponer máscaras o desabrochar vestidos en la oscuridad de los encajes y las filigranas. Porque así como en el barroco, en la teoría y práctica de Sarduy no hay verdades, sino cuerpos, hay respuestas sin preguntas, hay idas sin regreso. Y allí salta lo latinoamericano en violenta pirueta, si no fuera porque también es cuento, ficción, metáfora: «causalidad acrónica, isomorfía no contigua».

Si esta piedra molestosa deformada en perla nos viene a entregar en bandeja de oro, reluciente, el movimiento: serpiente que se muerde la boca con la cola, por qué no, serpiente que es pájaro - Quetzalcóatl«lo que pesa y lo que vuela» (D’Ors), inaugurando ese quinto sol, Sol del Movimiento:

E1 Quinto Sol:

4-Movimiento su signo

Se llama Sol de Movimiento, porque se mueve, sigue su camino. $Y$ como andan diciendo los viejos, en él habrá movimientos de tierra, habrá hambre, y así pereceremos ${ }^{2}$.

\footnotetext{
${ }^{1}$ Severo Sarduy, Barroco (Buenos Aires: Editorial Sudamericana, 1974).

${ }^{2}$ Según un antiguo mito Náhuatl, vivimos en la quinta edad, la del «sol del
} 
Y ahí está el barroco: ese indio pintarrajeado, vestido hasta el delirio de los colores, con un cuchillo de obsidiana gritando en lo alto del teocalli la muerte que origina la vida, el movimiento, el eterno ciclo: ciclo de las estaciones, girar de los astros, forma de las frutas, bucle que es boca y que va de lazo a vuelta, a cruce, a camino, a circo, aro, león, fuego: viaje de la $\mathrm{A}$ a la $\mathrm{O}$ : barroco: escritura situada en un cruce de caminos que es un cruce de sentidos: catedral que se retuerce de lujuria entre sus curvas y sus oros: Cortés a las puertas de Tenochtitlán: América descubriendo a España.

Empecemos de nuevo, por el principio (si hay un principio): el puente que permite que una ideología se cuele dentro de otra para formar una tercera, que contrarios como individuo y libertad se aproximen, se toquen, con opuestos como sociedad y destino, no puede ser más que esa arma de todos los filos - lo barroco-, que como bien lo señala Eugenio d'Ors, sobrevive como energía -eón- incuestionable dentro de lo humano, más allá y más acá de la cultura y las culturas ${ }^{3}$. Es por esto que España delira en América, que el puente se establece y se crea ese ser «que se parece a algo que aún no existe» (retombée): el latinoamericano, sin Edad Media y sin Renacimiento, pleno de fundaciones.

Con España todo llega desde lo alto y por lo bajo (recuérdese que los cristianos venían del cielo buscando oro), rompiendo e inaugurando una pluralidad de sistemas de valores que van a conseguir su propio valor en el encuentro con ellos mismos: relajación de la moral y nueva moral; ya el hombre español es el otro cuando toca América, y lo mismo el indio y más tarde el negro.

Al desembarcar en América, y pasados unos pocos años de intromisión entre lo verde de lo mismo del trópico, los españoles comenzaron a hacerse diferentes, adquirieron nuevos hábitos, cambiaron la faz de sus ropajes y sus costumbres: poco a poco se situaban en un mundo que los sembraba en la imaginación tanto como en la nueva realidad ${ }^{4}$.

Angel Rosenblat, en su imprescindible libro Los conquistadores y su lengua, nos demuestra que es el idioma de las clases medias y superiores españolas el que viene a conformar la base del español americano:

Ya hemos visto la escasísima proporción de campesinos en toda la primera época y la también escasa gente de los diversos oficios. En cambio, la cantidad de hidalgos, de funcionarios y de clérigos era ex-

movimiento». Miguel León Portilla, Los antiguos mexicanos (México: Fondo de Cultura Económica, 1968), p. 18.

${ }^{3}$ Eugenio d'Ors, Lo barroco (Madrid: Editorial Aguilar, 1964).

${ }^{4}$ Sobre esta integración de lo español en lo americano véase Alfredo A. Roggiano, En este aire de América (México: Editorial Cultura, 1966). 
traordinariamente grande, y aún mayor su influencia. Hay que tener además en cuenta que en España no ha habido nunca una distinción radical entre clase superior o ilustrada y pueblo (en contraste con Francia, por ejemplo), y que nunca ha sido muy grande la distancia entre el castellano culto y el popular (la lengua popular nutre toda la literatura española). En la formación del español americano del siglo xvi hay que tener presente no sólo la alta proporción de hidalgos y de gente culta, sino la hidalguización general ${ }^{5}$.

$\mathrm{Y}$ este idioma de clase aristocrática, culto y caballeresco, va a fundirse con la ampulosidad y el lirismo de las lenguas indígenas. Hablando de las particularidades de la poesía náhuatl, Angel $M$. Garibay señala lo siguiente:

Extraña poesía para nuestros oídos, pero no menos refinada. De paso notaré la modalidad... de dar a las palabras doble sentido y traspasar las imágenes a una esfera que no es la directa. $\mathrm{O}$ sea, en otras palabras más comunes: una manera de barroquismo o culteranismo de la poesía ${ }^{6}$.

Como uno de los productos de esta fusión (superposición, montaje), muy pronto el doctor Juan de Cárdenas, en su libro Problemas y secretos maravillosos de las Indias (1591), notará que «los autores criollos tienden constantemente al disfraz, nunca se abren totalmente, encubren sus ideas, sus sentimientos y sus voliciones, y en el caso que los expresen, los disfrazan con toda clase de galas retóricas...» ${ }^{7}$.

¿Estamos, entonces, lejos de la máscara, del disfraz, de la elipsis, de la parodia, de la mímesis, del teatro, del juego, del travestismo, de los espejos que viene a reflejar Sarduy en esos apuntes para una arqueología de la superficie que es su libro Barroco? No, por supuesto. Pero revisemos rápidamente otro acercamiento a Sarduy desde la colonia.

La pirámide truncada e invertida —estípite-, conformación esencial de la columna barroca, nos servirá para encontrarnos con otro de los postulados de la nueva retórica: la palabra como cuerpo.

5 Angel Rosenblat, Los conquistadores y su lengua (Caracas: Universidad Central de Venezuela, 1977), pp. 69-70. Para una información general -crítica y bibliográfica- sobre la relación entre los barrocos de España y América, véase el excelente ensayo de Alfredo A. Roggiano «Acerca de dos barrocos: el de España y América» (Madrid: El barroco en América, XVII Congreso del Instituto Internacional de Literatura Iberoamericana, tomo I, 1978), pp. 39-47.

- Angel María Garibay, Poesía Náhuatl (México: Universidad Nacional Autónoma de México, 1964), tomo I, p. XXXIV.

7 Angel Rosenblat, op. cit., p. 79. 
De limitar el cuerpo del hombre dentro de una figura geométrica, integrada por una línea horizontal a la altura de los hombros y de cuyos extremos parten dos líneas convergentes hacia abajo que llegan al ancho de los pies juntos, resultó la sección vertical del estípite, que ya en su propio volumen de pirámide truncada e invertida se seguiría empleando en Grecia, principalmente como símbolo religioso, ahora en esa forma y en sustitución del cuerpo donde se colocaría la cabeza del dios Hermes, barbado, muchas veces con el falo en el frente de la pirámide invertida y a una altura que, como en el estípite, no siempre coinciden con la real y con dos breves apéndices laterales como muñones en lugar de brazos ${ }^{8}$.

La tradición de la forma estípite (Hermes), que, como hemos visto, viene de lo ancestral griego y tenía un carácter religioso, al llegar a Roma se convirtió en Mercurio y se le consideró entonces el dios del libertinaje, así como el dios de la germinación y el genio de la vegetación rica y abundante. Hermes era también el guía en los caminos desconocidos, el conductor de las almas en sus peregrinaciones por el infierno y también de las imágenes que se forman en los sueños ${ }^{9}$.

Al pasar a América, el signo viene vivo, pero elidido en su funcionalidad ornamental, afirmando esas normas barrocas como el esplendor y la ostentación, el esfuerzo, la persistente tendencia a la curva, el erotismo y el éxtasis (patetismo y morbidez), la tendencia a lo pictórico: todos esos valores que encontramos en el churrigueresco y en toda la arquitectura colonial; el estípite es una metáfora en movimiento (metáfora al cuadrado: pirámide truncada e invertida sobre pirámide indígena igual a desorden que produce un orden, o viceversa. La pirámide indígena es lo elidido en el estípite. Era imaginaria: Quetzalcóatl enseñando a Hermes el Kibalión en Teotihuacán) que esconde ese surgir del cuerpo, pero que es cuerpo presente, cuerpo acentuado hasta los límites extremos de piel y superficie: iglesia como rito y concepto; arquitectura como poesía: fiesta, carnaval, vegetación rica y abundante; cuerpo como escritura, palabra como cuerpo (Eros).

Más claros y más oscuros no podemos ser entonces en América Latina: Sarduy ve la esencialidad barroca en la lengua y así lo afirma ${ }^{10}$. Nosotros vemos en esta exposición fragmentaria de sus teorías que el barroco es también una lectura, una creación especular. Por tanto, fun-

\footnotetext{
${ }^{8}$ Víctor Manuel Villegas, El gran signo formal del barroco (México: Imprenta Universitaria, 1956), p. 25.

${ }^{9}$ Véase J. Richepin, Mitología clásica (México, 1952), tomo I.

${ }^{10}$ Severo Sarduy, Escrito sobre un cuerpo (Buenos Aires: Editorial Sudamericana, 1969), p. 63.
} 
damos una tradición para poder luego transgredirla: fuente del placer sin un objeto otro; amor sin procreación; vocablo sin referente.

\section{Desplazamientos ${ }^{11}$}

La noción de barroco en Sarduy se divorcia de las interpretaciones corrientes en América Latina al cimentar sus asertos no sólo en la particularidad de un continente mestizo, sino en la generalidad de una estructura de pensamiento que concuerda con el ritmo del universo. Su viaje, que va desde el geocentrismo hasta las teorías del Big Bang y el Steady State, trata de ilustrar que la naturaleza de la verdad es relativa y que el juego de la razón, al acercarse al fuego dorado de lo inmóvil en movimiento, no puede sino saltar esa cuerda de ida a la superficie. Al perder la ilusión del eje central, estático, centro dominante y dominado, una ruptura (escisión) se hace palpable, pero esta ruptura es como un descenso (a la inversa, que es lo mismo; D’Ors habla de la "eterna elevación de las cosas contra la ordenanza clásica del espíritu» ${ }^{12}$ ) del alma al cuerpo: hacer realidad que lo que vuela de la materia es su corporalidad:

Ta1 es la connotación teológica, la autoridad icónica del círculo, forma natural y perfecta, que cuando Kepler describe no un círculo, sino una elipse alrededor del sol, trata de negar lo que ha visto; es demasiado fiel a las concepciones de la cosmología antigua para privar el movimiento circular de su privilegio ${ }^{13}$.

Es obvio que el hombre, adherido a las patas de una racionalidad clásica, no pueda aceptar el correrse de ese centro en constante movimiento elíptico: "Algo se descentra o, más bien, duplica su centro, lo desdobla», afirma Sarduy ${ }^{14}$. Kepler, el Caravaggio, el Greco, Rubens, Borromini, Velázquez, Góngora, serán entonces, para Sarduy, los abanderados que han de poder ver al otro lado del espejo; atletas de la libertad, no pueden dejar de correr esa maratón hacia el infinito. "La elipsis, figura mal conocida, perturba justamente porque representa la horrorosa

${ }^{11}$ Desplazamiento m. Mar. Volumen de agua que desaloja un buque (Larousse). «Repetidamente se ha señalado la gran contribución del vocabulario marítimo al léxico general de América, sin duda desde la primera hora.» Angel Rosenblat, op. cit., p. 31.

${ }_{12}$ Eugenio d'Ors, op. cit., p. 142.

${ }_{13}$ Severo Sarduy, Barroco, p. 55

${ }^{14}$ Ibid., p. 56. 
libertad del lenguaje, que, de alguna manera, no tiene medida obligatoria: sus módulos son totalmente artificiales, puramente aprendidos» ${ }^{15}$.

E1 lenguaje se hace perverso, inútil, ocioso, asiste al festín de los artificios; se llena de luz porque la absorbe y la irradia, como si dependiera del ir y venir de sus rayos la energía que nos entrega a lo vital; las palabras cambian de vestido como muñecas en una vitrina acribillada por los reflejos:

La metáfora en Góngora es ya, de por sí, metalinguística, es decir, eleva al cuadrado un nivel ya elaborado del lenguaje, el de las metáforas poéticas, que a su vez suponen ser la elaboración de un primer nivel denotativo, «normal», del lenguaje ${ }^{16}$.

Al suprimirse el referente, el significado queda vaciado de contenido, la palabra misma es la cosa.

\section{HACIA LA GRAN EXPLOSIÓN}

Comprender, en el sentido de aprehender o de vivir con lo de afuera las teorías sobre el barroco de Severo Sarduy, implica (paradójicamente) la necesidad de una participación, a nivel creativo y vivencial, de ese movimiento de desplazamiento, de ubicación en un sitio otro, a que nos viene acostumbrando la relatividad de lo moderno. Porque, si nos circunscribimos al mundo de la física, podemos observar que a partir de Einstein, Planck, De Broglie, etc., la factibilidad de lo imposible puede llegar a ser del orden del dos por dos cuatro: la imaginación que representa, que dibuja el orden de las cosas, tiene que saltar las barreras de su propio centro, ya que éste se escinde conformando un diagrama que señala tanto la quietud como el movimiento, el fin como el principio, para poder acceder a la carne del barroco, a su terrestre y, por tanto, cósmico postulado sensible.

Comprobamos así que vivimos en un mundo alimentado ferozmente por las contradicciones, por un girar enloquecido y vertiginoso de los opuestos en torno a la conciencia del vacío: ausencia de un referente que nos permita ubicarnos en nuestras cómodas poltronas mentales, presencia de una superficie que al girar sobre sí misma nos da la cara de

\footnotetext{
p. 87 .

${ }^{16}$ Severo Sarduy, «El barroco y el neobarroco», en América Latina en su literatura, ed. César Fernández Moreno (México: Siglo XXI, 1972), p. 169.
}

${ }^{15}$ Roland Barthes, Barthes por Barthes (Caracas: Editorial Monte Avila, 1978), 
una única realidad, como la cinta de Möebius; fricción y anulación o desaparición del dualismo continente-contenido; vaso órfico, no vaso comunicante.

Y es ésta una historia donde los hechos suceden después de su narración, donde el tiempo de espera viene luego del tiempo de encuentro, donde entramos a un espacio antes de que éste exista para nuestro cuerpo: salto metafórico al cuadrado que nos permitirá bautizar al abuelo:

Nada puede situarnos, definir dónde estamos en un espacio «absoluto, verdadero y matemático» -newtoniano-: el continente uniforme, el soporte infinito e imperturbable de las cosas, está desprovisto de toda realidad ${ }^{17}$.

Es lógico percibir que si aceptamos lo anterior nos encontraremos de pies y manos ante la presencia del vacío: hueco negro que nos abisma por su no realidad. La página puede llenarse con el hormigueo espejeante de los vocablos o quedar en blanco (horror al vacío/zen). Relatividad de lo sensible: sensualidad.

Podríamos suponer también, para no apartarnos del campo de la físi$\mathrm{ca}$, que los paralelismos especulares (cosmológicos) que ofrece Sarduy como teoría general del barroco y el neobarroco constituyen un sistema de referencia, a la manera einsteiniana; es decir, "una especie de red o andamiaje mecánico, respecto al que se toman las distancias respectivas» ${ }^{18}$. Y que a pesar de la movilidad/quietud -Yin Yang, Big Bang/ Steady State - constante de sus aseveraciones, al plantear esa elipse (ese desperdicio, ese gasto inútil, podríamos decir), en la cual uno de sus centros escondidos se desplaza constantemente, Sarduy está creando un sistema de coordenadas en el cual podemos inscribir el barroco.

${ }^{17}$ Severo Sarduy, Barroco, pp. 84-85.

${ }^{18}$ Albert Einstein y Leopold Infeld, La fisica aventura del pensamiento (Buenos Aires, 1958), p. 137. 
